\title{
Martin Buber's Notion of Grace as a Defense of Religious Anarchism
}

\author{
Sarah Scott
}

Manhattan College, USA

"I asked Buber why God's grace finds hardly any place in his work. He explained: 'I write theology for men, not for God'”.

- David Flusser ${ }^{1}$

I reconstruct Martin Buber's conception of grace to show its importance for unifying his religious orientation and anarchist tendencies. I first lay out an Augustinian account of grace and concomitant defense of hierarchy and submission. I then examine Buber's anarchism and previous analyses of his notion of grace, which were incomplete insofar as they ignored his redefinition of what is given by grace and who gives these gifts. The primary gifts of grace he identifies are who we are (meant to be), moral norms and reality, each of which come to us not just from God, but also from relations with other creatures. Buber corrects the classic Augustinian notion of grace by replacing radical dependence on God with radical creaturely interdependence. Once hierarchy and submission to an inscrutable authority are no longer taken to be necessary for human flourishing, we are free to think along broadly anarchist lines.

The author wishes to thank the editors and reviewers for their helpful comments.

${ }^{\text {I }}$ David Flusser, 'Afterword', in Martin Buber, Two Types of Faith: A Study of the Interpenetration of Judaism and Christianity (New York: Syracuse University Press, 2003), pp. 175-229 (p. 198).

How to cite this book chapter:

Scott, S. 2020. Martin Buber's Notion of Grace as a Defense of Religious Anarchism. In: Christoyannopoulos, A. and Adams, M. S. (eds.) Essays in Anarchism and Religion: Volume III. Pp. I89-222. Stockholm: Stockholm University Press. DOI: https://doi.org/Io.I 6993/bbb.f. License: CC-BY 


\section{Introduction}

In order to show the compatibility between a religious orientation and anarchism I shall reconstruct Martin Buber's (I 878-I965) notion of grace [Gnade]. Well known for developing a distinction between I-Thou and I-It relations in his 1923 Ich und Du [I and Thou], this great Jewish thinker authored more than 700 books and papers on subjects ranging from philosophy and political structures to education and religion, including commentaries on both Jewish and Christian theology and, with Franz Rosenzweig, a new German translation of the Bible. ${ }^{2}$ Buber was also quite politically active. In his youth he advocated for cultural Zionism and was close friends with the socialist anarchist Gustav Landauer. When the Nazis came into power Buber engaged in "spiritual resistance" by organizing Jewish adult education programs, despite being banned from public speaking. Once in Palestine, Buber advocated for Jewish-Arab parity and a bi-national state. Inter-religious dialogue was a special concern of his. In keeping with this proclivity, and building on Buber's own stated differences with the positions of Christian traditions, this work will use Augustinian views on grace as a foil to elucidate Buber's views on grace. Through this contrast I join those commentators who direct our attention to the ways Buber offers a genuine alternative and who aim to correct the common, but misguided, tendency to subsume his stance under Christian frameworks.

I begin with an Augustinian account of grace and concomitant defense of hierarchy and submission. This shows that so long as the notion of grace assumes an independent being deigning to bestow inscrutable gifts on radically dependent beings, the replication of this power structure between human beings seems justified by the "as above, so below" adage. I argue that Buber is able to propose very different power structures while retaining the "as above, so below" principle because he reconceives the nature

${ }^{2}$ See Martin Buber: A Bibliography of His Writings I898-I978, compiled by Margot Cohn and Rafael Buber (Jerusalem: The Magnes Press; München: K.G. Saur, I980), which lists I4I 6 entries. See also the twenty-two volume German critical text edition of Buber's writings: Martin Buber Werkausgabe, eds. Paul Mendes-Flohr and Bernd Witte (Güterloh: Güterlohsloher Verlaghaus, 200Iff.). 
of grace. In order to illustrate the compatibility of his political and religious views I analyze his "anarchism", which turns out to be not a simple advocacy of stateless or lawless societies, but a multifaceted position that has garnered numerous appellations. Joining the various accounts of commentators together produces the inelegant yet nuanced description of Buber's position as "topian-communitarian-socialist-federalist-anocracy". I then examine previous analyses of his notion of grace, which were incomplete insofar as they ignored his redefinition of what is given by grace and who gives these gifts. The primary gifts of grace Buber identifies are who we are (meant to be), moral norms and reality, each of which come to us not just from God, but also from relations with other creatures. For Buber, grace may occur between persons, and is not just bestowed by an inscrutable, higher being to a lower being. Buber thus corrects the classic Augustinian notion of grace by replacing radical dependence on God with radical creaturely interdependence. Once hierarchy and submission to an inscrutable authority are no longer taken to be necessary for human fulfillment, we are free to think along broadly anarchist lines.

\section{As above, so below}

In order to better understand the role that grace plays in uniting Buber's religious and political philosophy, it helps to compare him to a familiar figure who can act as a foil. Buber identifies the views of the Augustinian tradition as directly opposed to his own: "the tendency from Augustine to the Reformation was to see faith as a gift of God. This ... resulted in the retreating into obscurity of the Israelite mystery of man as an independent partner of God". ${ }^{3}$ As a familiar, albeit simplified, Augustinian story goes, although happiness and goodness are natural, we are incapable of attaining these states on our own. ${ }^{4}$ Each stage on the way to the fulfillment

${ }^{3}$ Martin Buber, Eclipse of God: Studies in the Relation Between Religion and Philosophy, trans. by Maurice Friedman (Atlantic Highlands, NJ: International Humanities Press, I988), p. I07.

${ }^{4}$ E.g., Augustine, The Confessions, trans. by Maria Boulding (Hyde Park, NY: New City Press, 200I), VI.20, p. I Iо: "no one can be continent except by your [God's] gift". 
of happiness and goodness is driven by divine grace: prevenient grace leads to faith, faith helped by grace creates a will to rightly ordered love, will helped by grace actualises rightly ordered love, rightly ordered love produces meritorious works, and meritorious works lead to further grace and eternal life. All faithful prayer for grace is conducted by those who have already received grace: "it is not in our power to live rightly, unless while we believe and pray we receive help from him who has given us the faith to believe that we must be helped by him". ${ }^{5}$ While there may be subsequent merit, there is no antecedent merit, for subsequent merit is ultimately the result of unmerited grace: "Everything, not only my salvation but even my choice to seek it, depends on whether God chooses that I will receive this gift of grace and persevere in to the end, and not only do I have no say over God's choice but I am (by Augustine's reckoning) in no position to know anything about it". ${ }^{6}$

This model of grace supports a particular understanding of the proper ordering of relationships between humans. Having established God as our inscrutable divine sovereign, the Hermetic "as above, so below; as below, so above" adage can be used to defend the necessity of submission to human sovereigns. Augustine, for example, draws an analogy between the ordered obedience of body to mind, household to paterfamilias, citizens to sovereign, and humanity to God:

'How is it that God rules man, the soul rules the body, the reason rules lust and the other perverted elements in the soul?' By this analogy it is shown plainly enough that servitude is beneficial for some men, and that servitude to God, at least, is beneficial to all. ${ }^{7}$

5 Augustine, Concerning the City of God, Against the Pagans, trans. by Henry Bettenson (London: Penguin Books, 2003), XIX.4, p. 852.

${ }^{6}$ Phillip Cary, Inner Grace: Augustine in the Traditions of Plato and Paul (New York: Oxford University Press, 2008), p. IoI.

7 Augustine, City of God XIX.2 I, p. 883. See City of God XIX.I6, p. 876, for another application of the "as above, so below" principle: "Now a man's house ought to be the beginning, or rather a small component of the city, and every beginning is directed to some end of its own kind, and every component part contributes to the completeness of the whole of which it forms a part. The implication of this is quite apparent, that domestic peace contributes to the peace of the city - that is, the ordered 
This argument for the necessity of hierarchical relationships of governance between humans may be summarized as follows:

(I) God is our sovereign

(2) Human nature is radically dependent on God

(3) Without this dependency it is impossible for humans to attain virtue

(4) Servitude to God is beneficial to all

(5) As above, so below

(6) Therefore, dependence on / servitude to a human sovereign is beneficial for at least some humans.

Following the "as above, so below" adage, conceptions of prevenient grace and sovereignty go hand in hand; hierarchical ordering is a necessity given our flawed will and incapacity to attain virtue on our own. Those who resist the concomitant notions of prevenient grace and hierarchical ordering, and maintain greater human freedom and personal responsibility, such as the Pelagians, are deemed to have at best a naïve account of human nature and at worst to be dangerous heretics. ${ }^{8}$

Two main counter-arguments could be used to dismantle the classic Augustinian defense of the necessity for submission to a hierarchical order and show the possibility of a religious anarchism. One tactic would be to question premise (5), that is, this application of the "as above, so below" principle. Like all arguments that rest on analogy, we might question if there are not relevant points of disanalogy to consider. Even if we do accept an analogical argument linking macrocosm to microcosm, the general statement that servitude to God is beneficial might not produce a sufficient defense of specific political systems, each of which might have

harmony of those who live together in the house in the matter of giving and obeying orders, contributes to the ordered harmony concerning authority and obedience obtaining among the citizens". Even slavery is justified using this analogy (City of God XIX.I 5, p. 875).

${ }^{8}$ For a more favorable account of the Pelagians than that of Augustine see Richard Fitch, 'The Pelagian Mentality: Radical Political Thought in Fifth Century Christianity', in Religious Anarchism: New Perspectives, ed. by Alexandre J. M. E. Christoyannopoulos (Newcastle upon Tyne, UK: Cambridge Scholars Publishing, 20I I), pp. 2-29. 
institutionalized varying forms of dependence or servitude. The other tactic would be to question premises (I) $-(4)$ and revise our conception of grace. If we replace the image of our relationship to God as one of subject to sovereign with an image of a relationship between independent partners, which Buber calls the Israelite mystery, then we may be able to use this new imagery to rethink the nature of relations between humans.

If the second strategy is used the first is unnecessary. The "as above, so below" analogy can be kept intact if our understanding of our relationship to God alters simultaneously with our understanding of our relationship to one another. Buber provides an example of how to maintain the "as above, so below" analogy and use it to wed theology with political philosophy in support of religious anarchism. In I and Thou, he explains that to show "the close association of the relation to God with the relation to one's fellow-men" is his "most essential concern". ${ }^{9}$ He reemphasizes this point throughout his life, stating in 1964 that his one basic insight is that "the I-Thou relation to God and the I-Thou relation to one's fellow man are at bottom related to each other" ${ }^{\prime \circ}$ It is a central refrain of $I$ and Thou that "in the beginning is the relation". ${ }^{\text {I }}$ Beings are interdependent and constituted by their relationships. In I-Thou relations we are in the mode of presence. We dynamically receive and respond to the other as a spontaneous totality, which, even when the exchange is non-verbal, Buber refers to as dialogue. I-It, or monologic, relations are dominated by our capacity for holding onto the past and projecting into the future. Instead of embracing the totality and vital newness of the other, we interpret him through the lens of static categories. This allows us (we assume) to be able to predict his responses, and thus I-It relations lie behind every relationship of mere utility. While Buber recognizes the necessity of I-It modes, he cautions us that contemporary humanity suffers from an excessive

9 Martin Buber, I and Thou, trans. by Walter Kaufmann (New York: Simon and Schuster, I996), p. I7I.

to Martin Buber, 'Interrogation of Martin Buber', conducted by M. S. Friedman, in Philosophic Interrogations, ed. by S. and B. Rome (New York: Holt, Rinehart, and Winston, I964), p. 99.

II See, for example, Buber, I and Thou, p. 69. 
development of the capacity for I-It relations and an impoverished capacity for I-Thou relations. For the purposes of this study, what Buber calls his one basic insight or central concern, namely that our capacity to enter into dialogue with other creatures parallels our capacity to enter into dialogue with God, is especially important. Buber argues for interdependence throughout all of the levels of being. The nature of the partners alters the specific dynamics of the dialogue - we give language to beings that are below the threshold of language, we enter into language and give and receive with each other, and we create language to express what we receive from the transcendent $\mathrm{t}^{\mathrm{I} 2}-$ but the dialogic orientation of the subject is the same regardless of the partner. Our capacity to enter into relationship with other creatures is not qualitatively different from the capacity to enter into a relationship with God, though the other we are in a relation with is qualitatively different. This embrace of the "as above, so below" adage and yet rejection of accounts of independence and dependence in favor of an insistence on interdependence will provide the foundation for Buber's religious anarchism.

\section{Buber's "anarchism"}

With the basic problem of grace and the use of the "as above, so below" adage laid out, we are now in a position to first take a preliminary look at Buber's political philosophy, in particular, his "anarchism", and then take a preliminary look at his views on grace, in order to eventually unite these two strands of inquiry and develop a more complex view of each. Evidence for classifying Buber as a thinker with anarchist leanings comes from his close and sympathetic relationship with Landauer and writings such as Paths in Utopia (1945), which favorably discusses Pierre-Joseph Proudhon, Peter Kropotkin and Landauer, while critiquing Karl Marx and Vladimir Lenin, and the collection of essays Pointing the Way, which includes "Society and the State" (I95I) and

${ }^{12}$ Buber, I and Thou, p. 57. When he revisits this tripartite categorization in his 1957 Afterward to I and Thou, Buber recasts it as marking different degrees of capacity for mutuality, not language. See Buber, I and Thou, p. I78. 
"The Validity and Limitation of the Political Principle" (I953). ${ }^{\text {I3 }}$ However, few commentators have been satisfied affixing this label to a complex, unsystematic thinker. Part of the problem has to do with the term "anarchy", the etymology of which suggests a complete absence of government. Alexander S. Kohanski prefers the term "anocracy" to describe Buber's thought: "anocracy ... means a 'non-dominance' (a-kratia) rather than a 'non-government' (an-archia), not the abolition of the state but a curbing of its oppressive power". ${ }^{14}$ The appellation "anocracy" is used by Buber to describe the "anarchy" of both Kropotkin and Proudhon, but as we shall see, it more accurately describes his own political philosophy than the simple label "anarchy". ${ }^{\text {I5 }}$

When Buber elaborates what we can call his own anocracy, he distinguishes between two principles: the political and the social. The state tends to be governed by the political principle, but the two principles are not tied to specific organizations as they refer to two different modes of relation. While the political and social principles generally correspond to I-It and I-Thou modes, the latter denote general modes of existence while the former delineate modes of structural organization. Social relations are based on "common need or a common interest" and are the primary structures in which human beings are fulfilled. Political relations are secondary, and replace "association by subordination, fel-

${ }^{2} 3$ For an analysis of Buber as deeply influenced by Landauer's anarchism, see Samuel Hayim Brody, Martin Buber's Theopolitics (Bloomington, IN: Indiana University Press, 20I 8), especially Chapter I: 'The True Front: Buber and Landauer on Anarchism and Revolution'. Brody goes on to argue that Buber's thought is best understood as "Theopolitical Zionism"; Brody's work was published after the completion of this paper and I was regrettably unable to incorporate his insightful analysis. For more on the influence of Landauer on the development of Buber's philosophy of I-Thou relations see Paul Mendes-Flohr, From Mysticism to Dialogue: Martin Buber's Transformation of German Social Thought (Detroit, MI: Wayne State University Press, I989). For Landauer's own work, see Gustav Landauer: Anarchist and Jew, eds, Paul Mendes-Flohr and Anya Mali (Berlin/Munich: Walter de Gruyter Verlag, 20I4).

${ }^{14}$ Alexander S. Kohanski, 'Martin Buber's Restructuring of Society into a State of Anocracy', Jewish Social Studies, 34: I (I972), 42-57 (p. 5I).

I5 Martin Buber, Paths in Utopia, trans. by R. F. Hull (New York: Syracuse University Press, I996), p. 43; emphasis in the original. 
lowship by domination" ${ }^{16}$ While coercive and centralistic they are not in themselves bad or inhuman. Like the realm of I-It, they become dangerous when excessive and detached from what is essential. As Steven Schwarzschild explains, for Buber "evil and the State are both nothings, privations, the absence of thouness and of community respectively. The State is really 'absolute evil', insofar as Buber can have such a thing. But evil = the State must be lived with minimally, and it must be maximally redirected" ${ }^{17}$

Buber maintains that genuine society is not a mere aggregate of individuals, but is made up of mutual relations of smaller societies, each of which are in turn made up of mutual relations between persons, and praises Jewish village communes, with their decentralised, minimal political principle, as contemporary examples of genuine society. ${ }^{18}$ Consequently, Bernard Susser labels Buber's approach "anarcho-federalism", while Amitai Etzioni decides that Buber is best described simply as a "communitarian". ${ }^{19}$ In a renewed community, such as Buber fancied the Jewish village communes to be, there is a change in the apportionment of power as well as a change in the nature of power. Buber explains that the difference between administration and government lies in the measure of excess political power ("political surplus"), that is, domination and coercion, possessed by the state. ${ }^{20}$ Ideally the political principle is incrementally minimized to what is indispensible, while decentralization and freedom are incrementally pushed to what is maximal, such that at some point government qualitatively transforms and becomes mere administration. ${ }^{21}$ However,

${ }^{16}$ Martin Buber, 'Society and the State', in Pointing the Way: Collected Essays, ed. and trans. by Maurice Friedman (New York and Evanston, IL: Harper \& Row, I963), pp. I6I-76 (p. I6I).

17 Steven Schwarzschild, 'A Critique of Martin Buber's Political Philosophy: An Affectionate Reappraisal', in The Pursuit of the Ideal: Jewish Writings of Steven Schwarzschild, ed. by Menachem Kellner (Albany: SUNY Press, I990), p. I94 note 90 (p. 347).

I8 Buber, Paths in Utopia, p. 80 and p. I4I.

19 Bernard Susser, 'The Anarcho-Federalism of Martin Buber', Publius, 9:4 (I979), I03-I 5; Amitai Etzioni, 'Communitarian Elements in Select Works of Martin Buber', The Journal of Value Inquiry, 33: 2 (I999), I 5 I-69.

${ }_{20}$ Buber, 'Society and the State', p. I74.

2т Buber, 'Society and the State', p. I75. 
the Jewish village model should not be blindly copied or enforced, for change must be "adapted and proportioned to whatever can be willed and done in the conditions given". ${ }^{22}$ The minimum or maximum is constituted by an ever-shifting "line of demarcation" specific to each historical moment and place, or topos. ${ }^{23}$

Like the religious socialists Paul Tillich, Leonard Ragaz and Eugen Rosenstock-Huessy, Buber maintained that socialism, which he defines as genuine community, could not be understand via economic or political transformation but only by spiritual transformation. ${ }^{24}$ In "Three Theses of a Religious Socialism", Buber argues that I) socialism requires orientation to a common center, 2) the difference between authentic and inauthentic religious or socialist programs lies in the degree to which they serve relationship, whether of man to god or between men, and 3) religion and socialism meet and are authenticated in concrete personal life, not in programs. ${ }^{25}$ Since we are dealing with modes of relating and not with institutions, true revolution cannot come about merely through the overthrow of the state; we "cannot solve social problems by political means". ${ }^{26}$ Lasting, meaningful change to keep the political within its proper sphere occurs from the bottom up, through a revolution in the mode in which we relate to each other.

This revolution begins with individuals and their direct sphere of influence, when "their own inner 'statehood' is broken open". ${ }^{27}$ Since the state promises to its populace protection from both internal and external threats, it "fosters a perspective which allows differences of interest to appear as radical opposition" in

${ }^{22}$ Buber, Paths in Utopia, p. 56.

23 On the notion of a "line of demarcation", see Schwarzschild, "A Critique of Martin Buber's Political Philosophy: An Affectionate Reappraisal'.

${ }_{24}$ Buber co-founded Die Kreatur, the first high profile interfaith journal, with Eugen Rosenstock-Huessy. For Buber on Leonard Ragaz, see 'Religion and God's Rule', in A Believing Humanism: My Testament, I902-I965, trans. By Maurice Friedman (New York, Humanity Books: I999), pp. I09-I2.

25 Martin Buber, 'Three Theses of a Religious Socialism', in Pointing the Way: Collected Essays, ed. and trans. by Maurice Friedman (New York and Evanston, IL: Harper \& Row, I963), pp. I I2-I4.

${ }^{26}$ Buber, Paths in Utopia, p. $5 \mathrm{I}$.

27 Buber, Paths in Utopia, p. 48. 
order to justify its existence. ${ }^{28}$ This cultivated divisiveness and mistrust encourages an unhealthy individualism and pattern of relation, such that even outside of official state activities "men stand to one another in a 'statual' relationship" and seek to dominate and coerce one another. ${ }^{29}$ In contrast to the unhealthy individualism of the political, the social provides an authentic individuation of the whole person that enhances and is enhanced by community through "functional autonomy, mutual recognition and mutual responsibility"..$^{30}$ As the means of attaining the utopia - the restructuring of relationships — is the end of utopia itself, the formation of direct relationships with others constitutes revolutionary action and "utopian" vision is a misnomer for what should be called "topical" change. ${ }^{3 \text { I }}$ Consequently, Kohanski decides, "I would call Buber's socialism topian rather than utopian". ${ }^{2}$ Uniting all of the various features identified in Buber's political philosophy, we are left with the hybrid position: topian-communitarian-socialist-federalist-anocracy.

\section{Previous analyses of Buber's notion of grace}

We meet further complexity examining previous interpretations of Buber's notion of grace. Some confusion is due to the fact that religious writers have commonly used "grace" in two different ways. The first way is that utilised in our discussion of Augustine, where grace denotes an unmerited divine gift. However, because the notion of grace slipped into that of election, especially in the Augustinian Protestant tradition, we have a second usage of grace. Augustine argued that since original sin renders us incapable of obtaining virtue without grace, some of us must belong to the grace-receiving, virtuous "City of God" while others remain in

${ }_{28}$ Martin Buber, 'The Validity and Limitation of the Political Principle', in Pointing the Way: Collected Essays, ed. and trans. by Maurice Friedman (New York and Evanston, IL: Harper \& Row, I963), pp. 208-I9 (p. 216).

29 Buber, Paths in Utopia, p. 46.

30 Buber, Paths in Utopia, p. I3 I.

${ }^{31}$ Buber, Paths in Utopia, p. 8I.

${ }^{32}$ Kohanski, p. 50; emphasis in the original. 
the sinful "City of Man". ${ }^{33}$ Drawing on passages such as I Tim. I.9 (The law is not made for a righteous man, but for the lawless and disobedient, for the ungodly and for sinners, for unholy and profane) and Gal. 5:I 8 (But if ye be led of the Spirit, ye are not under the law), a radical Protestant argument is made that the elected are free from having to follow laws. ${ }^{34}$ We receive grace, understood as an unmerited gift. This gift allows us to have an ethic of grace, understood as action guided by rightly ordered love rather than law, such as occurs when we transition from a continent to a virtuous character. Critics of Buber have occasionally identified the second use of grace in his work, pejoratively calling him antinomian. ${ }^{35}$ This might be one way of reconciling religiosity with anarchism: no human sovereign or laws will be needed if we are living under an ethic of grace. However, the reading of Buber as antinomian is not quite accurate, for while Buber is dubious that morality is about following laws or that revelation can be lawgiving, he nowhere endorses the notion that election frees us from the constraints of the law. ${ }^{36}$ When he refers to the idea of the elec-

33 E.g., Augustine, City of God XXI.r3, p. 989: “... there is no escape for anyone from this justly deserved punishment, except by merciful and undeserved grace; and mankind is divided between those in whom the power of merciful grace is demonstrated, and those in whom is shown the might of just retribution". See also City of God XIV.28, p. 593; XV.2, p. 598; and XV.22, p. 637.

34 Authorized King James Bible, Pure Cambridge Edition.

35 The criticism of Buber as antinomian is documented and analysed in Maurice Friedman, Martin Buber: The Life of Dialogue, $4^{\text {th }}$ edn. (London and New York: Routledge, 2002), pp. 3I3-I4. Sam Berrin Shonkoff counters this charge, writing, "I prefer the term metanomian to antinomian in the case of Buber because he was not committed necessarily to the breaking of religious laws but rather to the expansion of religious practice beyond laws". See Sam Berrin Shonkoff, 'Metanomianism and Religious Praxis in Martin Buber's Hasidic Tales', Religions 9: I 2 (2018): 399, https://doi.org/I0.3390/rel9120399, note 8.

${ }^{6}$ E.g., Buber argues for "the constitutive impermanence of moral valuations" ('Images of Good and Evil', in Good and Evil: Two Interpretations, pt. I: Right and Wrong, trans. by R.G. Smith, pt. 2: Images of Good and Evil, trans. by M. Bullock [Upper Saddle River, NJ: Prentice Hall, I997], pp. 63-I43 [p. II ] ]); and writes "I do not believe that revelation is ever a formulation of Law" ('Martin Buber to Franz Rosenzweig, Heppenheim, June 24, I924', in The Letters of Martin Buber: A Life of Dialogue, ed. 
tion of Israel he describes it not as a static gift but as a calling that must be realized: "[election] does not indicate a feeling of superiority, but a sense of destiny. It does not spring from a comparison with others, but from the concentrated devotion to a task ... if you turn election into a static object instead of obeying it as a command, you will forfeit it". ${ }^{37}$

Buber's ostensible ethic of grace raises the problem of what gift of grace supports this ethic. What is the source of an ethic of grace if not divine election? When Buber writes of I-Thou relationships he emphasises will as much as grace: contemplation can turn into a relation "if will and grace are joined".$^{38}$ And,

The You encounters me by grace - it cannot be found by seeking. But that I speak the basic word to it is a deed of my whole being, is my essential deed. ... the relationship is election and electing, passive and active at once. ${ }^{39}$

This coincidence of will and grace has led to two criticisms. Commentators that have emphasised his mention of grace while ignoring his mention of will, such as Richard A. Cohen, complain Buber's description of I-Thou relations renders social action and accountability impossible: "the embrace of encounter happens by chance, by 'grace' ... Buber shows no way to get from encounter to community. Each is self-contained and accidental". ${ }^{\circ}$ Walter Kaufmann erroneously suggests Buber split humanity into two worlds - those who live in I-Thou relations and those who do not - misleadingly implying a replication of Augustine's City of

by Nahum N. Glatzer and Paul Mendes-Flohr [New York: Syracuse University Press, I996], p. 3I4, emphasis in the original).

37 Martin Buber, 'Nationalism', in A Land of Two Peoples: Martin Buber on Jews and Arabs, ed. by Paul Mendes-Flohr, (Chicago: University of Chicago Press, 2005), pp. 47-57 (p. 56).

$3^{8}$ Buber, I and Thou, p. 58.

39 Buber, I and Thou, p. 62.

$4^{\circ}$ Richard A. Cohen, 'Buber and Levinas — and Heidegger', in Lévinas and Buber: Dialogue and Difference, ed. by Peter Atterton, Matthew Calarco and Maurice Friedman (Pittsburgh, PA: Duquesne University Press, 2004), pp. 235-49 (p. 247). 
God and City of Man. ${ }^{4 \mathrm{I}}$ Etzioni declares, "Buber is closer to the Protestant than to the Catholic interpretation of virtue: we can find out if we are the chosen ones but not become so by working to become virtuous". ${ }^{42}$ Fritz Kaufmann goes so far as to call Buber "the Jewish 'Protestant'". ${ }^{43}$ These characterizations can be partially explained by the enthusiasm with which Protestant theologians embraced Buber and his I-Thou philosophy. Unfortunately, in their enthusiasm to make him their own they distorted his thought. Karl Heim, for example, described the discovery of the difference between I-Thou and I-It relations as a "Copernican Revolution" akin to that of Immanuel Kant. However, Heim then read an Augustinian Protestant understanding of grace into Buber's philosophy, and with it a notion of hierarchy that lead Heim to claim that one of the only ways one may have an I-Thou relationship is by submitting to the authority of one's dialogic "partner"!44 Meanwhile, those who emphasise Buber's mention of will while ignoring his mention of grace complain that his theology offers "cheap grace, in the sense that God's presence is supposedly easily available to the fully alert or attentive person". ${ }_{45}$ Buber does write, "No prescription can lead us to the encounter, and none leads from it. Only the acceptance of the

${ }^{4}$ Walter Kaufmann, 'I and You: A Prologue', in I and Thou, trans. by Walter Kaufmann (New York: Simon and Schuster, I996), pp. 7-48 (p. I7).

${ }^{42}$ Etzioni, p. I64.

43 Fritz Kaufmann, 'Martin Buber's Philosophy of Religion', in The Philosophy of Martin Buber: The Library of Living Philosophers, I2, ed. by Paul A. Schilpp and Maurice Friedman (La Salle, IL: Open Court, I967), pp. I 5 I-70 (p. 210).

${ }_{44}$ Karl Heim's usage of Buber is documented and analysed in Maurice Friedman, Martin Buber: The Life of Dialogue, $4^{\text {th }}$ edn. (London and New York: Routledge, 2002), p. I92 and pp. 324-25.

45 Michael Fishbane, 'Justification Through Living: Martin Buber's Third Alternative', in Martin Buber: A Contemporary Perspective, ed. by Paul Mendes-Flohr (Syracuse, NY and Jerusalem: Syracuse University Press and The Israel Academy of Sciences and Humanities, 2002), pp. I 20-32 (p. I30). Note this is not Fishbane's own view, which is explained below; he is summarizing an opposing view. 
presence [Gegenwart] is required to come to it". ${ }^{46}$ So is Buber an election-driven Augustinian Protestant or a will-driven Pelagian?

The answer is, of course, neither. In his insightful "Justification Through Living: Martin Buber's Third Alternative”, Michael Fishbane shows what happens to our picture of Buber's ethic of grace if we pay attention to his language use and range of literary activities, including translation. When Buber set out with Franz Rosenzweig to give a new German translation of the Bible they took up tzedakah and rendered it, along with other words with the stem tzedek, in such a way that suggests an alternative to both the Augustinian Protestant and Pelagian views of grace and will. Martin Luther had translated tzedakah as Gerechtigkeit [justice or righteousness], leading both rabbinic and Protestant interpreters to assume it denoted an earned merit or theological credit. Buber and Rosenzweig instead translated it as Bewährung [tested or proved true]. Bewährung is "the interiorization of a certain truth in the course of personal living ... verification in life". ${ }^{47}$ Fishbane shows how this Leitwort [keyword] pops up in Buber's writing. Buber writes, for instance, that the pure relation "cannot be preserved [bewahrt] but only put to the proof in action [bewährt]"..$^{8}$ This word choice points to a "third alternative", in which an ethic of grace is linked neither to willful good works nor to grace given faith:

Over against any sense of a religious accounting or justification before God through (fixed) righteous deeds, on the one side, or through faith (in a specific 'thing') on the other, Buber's use of Bewährung teaches the challenge of a living emunah in the course of life, such that one's faithfulness to the address of God's Presence is proved only through concrete acts in the world. ${ }^{49}$

Emunah refers to what Buber calls Jewish faith, which he describes as trust in the presence of a person, and which he contrasts to pistis, the Greek faith of Paul, which is faith in the truth of

\footnotetext{
${ }^{46}$ Buber, I and Thou, p. I 59.

47 Fishbane, p. I $24 \mathrm{ff}$.

${ }^{8}$ Buber, I and Thou, p. I63.

49 Fishbane, p. I28.
} 
a proposition..$^{50}$ In this third alternative, the gift of God's grace simply means that the lives of those that "prove true" are transformed by their trust in the presence of God: "The tzaddik (den Bewäbrten) is transfigured by this emunah, and thus, so to speak, is protected by God's grace". ${ }^{51}$

For our purposes, what is important about this third alternative is the way grace and will are intertwined through the notion of faith as an active trust. Dan Avnon describes this active trust as a state of "alert inactivity" and "active longing". ${ }^{52}$ Yet even this alert inactivity, or trusting readiness to enter into relation, is no guarantee the relation will actually occur. One cannot say that Buber is "offering cheap grace" such that God's presence comes to us through will alone. This would be magical thinking that would deny the reality of God as an independent other that cannot be conjured up but nevertheless enters into relation with us. In his analysis of Psalm 73 Buber explains that the opening line, "Surely God is good to Israel: to the pure in heart", is not a commentary on prevenient grace or meritorious reward for those who are pure. Instead it is a description of what it is like to "prove true" through emunab:

[It] does not mean that God rewards him with his goodness. It means, rather, that God's goodness is revealed to him who is pure in heart: he experiences this goodness. In so far as Israel is pure in heart, becomes pure in heart, it experiences God's goodness. ${ }^{53}$

50 Martin Buber, Two Types of Faith: A Study of the Interpenetration of Judaism and Christianity, trans. by Norman P. Goldhawk (New York: Syracuse University Press, 2003), passim.

${ }^{5}$ Fishbane, p. I3I.

52 Dan Avnon, Martin Buber: The Hidden Dialogue (Lanham, MA: Rowman \& Littlefield Publishers, Inc., I998), p. 6r: “'And I will wait for YHVH who hides his face from the house of Ya'akov, and I will incline towards him' [Isa. 8:I7] ... the limmud [here a rare form of L/M/D meaning "disciple" or "a state of continuous study"] combines a state of anticipation, a form of alert inactivity (indicated by the phrase heekeetee l'YHVH, 'I will wait for YHVH') and an inner inclination, an active form of longing (designated by keeveetee loh, usually translated as 'I will look for Him')".

53 Martin Buber, 'Right and Wrong', in Good and Evil: Two Interpretations, pt. I: Right and Wrong, trans. by R.G. Smith, pt. 2: Images of Good and 
Throughout his analysis Buber emphasises activity: "The Presence acts as counsel: God counsels by making known that $\mathrm{He}$ is present. ... [Man] is not relieved of taking and directing his own steps". ${ }^{54}$ Faith is not a cognitive state but a way of life, and God is not a proposition but a presence with whom one is in relation. This presence transforms us, but it does not remove our responsibility for our part of the relationship.

\section{A fresh start: what is given by grace?}

With their attention to language and the range of Buber's literary endeavors Fishbane and Avnon help resolve the question of how to relate Buber to Christian notions of will, election and righteousness. However, we are left with the question of how to reconcile Buber's religious views with his anarchist tendencies. To answer this we must take a fresh look at Buber's notion of grace. We can take as our starting point a statement by Friedrich Nietzsche that Buber mentions twice in I and Thou: "You take, you do not ask who it is that gives". ${ }^{55}$ In his first reference to this statement, Buber responds, "Man receives, and what he receives is not a 'content' but a presence, a presence as strength". ${ }^{56}$ Buber elaborates that receiving this presence awakens us to the fact of reciprocity: a presence is given and we respond with our presence. With this reciprocity "nothing can henceforth be meaningless. The question about the meaning of life has vanished". ${ }^{57}$ In his second reference Buber responds, "That may be so - one does not ask, but one gives thanks"..$^{8}$ The obvious answer - so obvious that it does not have to be explicitly addressed - to the question "Who gives?" is that God gives. The less obvious answer to "What is given?"

Evil, trans. by M. Bullock (Upper Saddle River, NJ: Prentice Hall, I997), pp. 3-60 (p. 34).

${ }_{54}$ Buber, 'Right and Wrong', p. 43.

55 Friedrich Nietzsche, 'Ecce Homo', in On the Genealogy of Morals and Ecce Homo, trans. by Walter Kaufmann and R.J. Hollingdale (New York: Vintage Books, I989), pp. 20I-335 (p. 300): “Man nimmt, man fragt nicht, wer da gibt".

${ }_{56}^{6}$ Buber, I and Thou, p. I 58.

57 Buber, I and Thou, p. I 58.

${ }_{58}^{8}$ Buber, I and Thou, p. 176. 
is that his presence is what is given. Yet it is precisely where an answer seems the most obvious that we ought to give the question a second look. What exactly is it that we receive that gives such meaning to our life?

Buber describes three main things as gifts of grace or revelation: who we are (meant to be), moral norms and reality. While deferring the metaphysical question of which comes first, essence or existence, Buber makes the phenomenological claim that we do not experience our own identity as something we freely make: "We are revealed to ourselves - and cannot express it otherwise than as something revealed".59 Yet we are not ourselves as if we were elected so; we are still charged with the responsibility to actualise ourselves, and sometimes this responsibility is not fulfilled. On the one hand, the choices we make, and our relations to others, are no different from who we are. On the other hand, we are not simply our choices because we are also who we were called to be but are not yet, and perhaps never will be. We are also the ability to judge the difference between the two, which is to say, we have a conscience. As Buber describes it, the conscience is not just a gauge of right and wrong, but is the faculty that "compares that which he is with that which he was called to become". ${ }^{60}$ The conscience is the "ever-renewed self-confrontation of the person with the image of what he was destined to be and what he has relinquished". ${ }^{61}$ Just as one does not freely invent the image our conscience shows us of our ideal or "true" self, we also do not freely invent moral norms, which even when absolute do not compel. Buber insists:

One can believe in and accept a meaning or value, one can set it as a guiding light over one's life if one has discovered it, not if one has invented it. It can be for me an illuminating meaning, a direction-giving value only if it has been revealed to me in my meeting with Being, not if I have freely chosen it for myself from among

59 Martin Buber, Eclipse of God: Studies in the Relation Between Religion and Philosophy, trans. by Maurice Friedman (Atlantic Highlands, NJ: International Humanities Press, I988), p. I35.

60 Buber, Eclipse of God, p. 87.

6I Martin Buber, 'People and Leader', in Pointing the Way: Collected Essays, ed. and trans. by Maurice Friedman (New York and Evanston, IL: Harper \& Row, I963), pp. I48-60 (p. I 53). 
the existing possibilities and perhaps have in addition decided with some fellow-creatures: This shall be valid from now on. ${ }^{62}$

Despite the language of revelation, we have an active relation to these norms, as we do to who we are. Each of us must actualise what is received. Similarly, we discover what is real, but nevertheless actively participate in its unfolding. In a striking account of our relationship to what is real, Buber describes reality as if it is an agent, our partner in life:

Although I myself have chosen it for myself, it guides me so that in proceeding I do not confound it with another and thus miss it; it stands by me. It must be one that has produced me and one that is ready, if I entrust myself to it, to bear me, to guard me, to educate me. ${ }^{63}$

This passage sums up our relationship to what we receive as gifts of grace. We receive and are produced, guided and educated by the image of who we are meant to be, moral norms and reality; we are also active participants who trust what we receive [emu$n a b]$ and choose to prove this in our actions [bewähren]; and the relationship between what is received and our response constitutes the meaning of our life.

The specific gifts of grace we receive - our self, moral norms, reality, and the knowledge of all three - is not far from what our foil Augustine asserts. However, Augustine sees only a relation to God in all three revelations; all three come directly from God in the guise of the "inner teacher" and sociality plays no role in their acquisition. ${ }^{64}$ The "inner teacher", also called inner truth or inner light, or more plainly, God or Christ, provides not only a priori

${ }^{62}$ Buber, Eclipse of God, p. 70. Buber is writing in opposition to Jean-Paul Sartre's "Existentialism is a Humanism".

${ }^{63}$ Martin Buber, 'Education and World-View', in Pointing the Way: Collected Essays, ed. and trans. by Maurice Friedman (New York and Evanston, IL: Harper \& Row, I963), pp. 98-I05 (p. 99).

${ }^{64}$ For an analysis of Augustine's argument for semantic individualism, which may be opposed to a social theory of language acquisition, see Gareth B. Matthews, 'Augustine on the Teacher Within', in Augustine's Confessions: Critical Essays, ed. by William E. Mann (Lanham, MD: Rowman \& Littlefield Publishers, Inc., 2006), pp. 3 I-43 (p. 34 ff). 
truths, but all veridical judgments, including the rational inferences of defeasible arguments (e.g., from analogy). For instance, when describing how he learned to speak, Augustine relates, "I taught myself, using the mind you [God] gave me". ${ }^{65}$ The capacities given to us by the inner truth come to us as acts of grace, and not at all from the educative forces of other persons:

A person thus made new considers your [God's] truth and understands it. He does not need some other human to explain it to him so that he may imitate his own kind; you explain it to him, so that he can discern for himself what is your will, what is good and pleasing to you and perfect. ... He becomes a Spirit-filled person, fit to judge of any matters that call for judgment, though he himself is not subject to the judgment of his fellows. ${ }^{66}$

Human authorities only teach in two ways: I) insofar as they point to realities that we would not normally have seen but, using the inner light, do understand upon indication and 2) as privileged witnesses to truths that cannot yet be seen by us and hence have to be believed in before they can be understood (if they are ever understood). Regardless of the type of pointing practiced by our teachers, it is the inward truth that allows us to judge to what signs are pointing, and to judge the veracity of the inference. ${ }^{67}$

On the basis of this epistemology, Augustine maintains that others are not terribly helpful for recognizing the meaning of our life, and are typically harmful insofar as they direct our attention and love toward the wrong things. For example, Augustine attributes his youthful theft of pears to an "exceedingly unfriendly form of friendship," where his "friends" merely served as an audience for his displays of freedom and power. ${ }^{68}$ When discussing truer friends, Augustine still finds room for lamentation at his response to their death: "Woe to the madness which thinks to cherish human beings as though more than human!" ${ }^{69}$ Augustine

\footnotetext{
${ }_{65}$ Augustine, Confessions I.I3, p. 2 I.

${ }_{66}$ Augustine, Confessions XIII.32, p. 294.

${ }^{67}$ Augustine, 'The Teacher', in Augustine: Earlier Writings, ed. by J. H. S. Burleigh (Philadelphia, PA: The Westminster Press, I953), pp. 69-IOI (passim).

68 Augustine, Confessions II.I7, p. 42.

69 Augustine, Confessions IV.I2, p. 64.
} 
believes he should have loved God more than the transient and finite beings he called friends. The creature would seem to be a poor and misguided substitute for the creator. But in Buber there is no question of substitution or contest, though fleeting I-Thou creature-creature relations are contrasted to the eternal I-Thou relationship each creature has with God. With this reframing, we deepen creature-creature relationships in order to make them as eternal as possible, and cherish the preciousness of the other, "a creature, trivial and irreplaceable", and our relationship with them all the more because of immanent and inescapable separation and death. ${ }^{\circ}$

\section{Who gives grace?}

This is not a minor difference between the two thinkers. Buber modifies the classic Augustinian notion of grace by replacing radical dependence on God with radical creaturely interdependence. He hence would agree with the latter part of Augustine's claim, "no one who sees can boast as though what he sees and the very power to see it were not from you [God] — for who has anything that he has not received?", but would take issue with the first part..$^{7 \mathrm{I}}$ Much of what we receive comes to us not just from God but also through relations with other persons, and even non-human entities. Buber maintains, for instance, that both who we are and what is real only reveal themselves through relations with others:

It is in encounter that the creation reveals its formhood [Gestaltigkeit]; it does not pour itself into senses that are waiting but deigns to meet those that are reaching out. ... No thing is a component of experience or reveals itself except through the reciprocal force of confrontation..$^{2}$

Reality only reveals itself to those who, in "alert inactivity" and "active longing", reach out to it, while our individuation only occurs through relations with others. These need not always be

\footnotetext{
$7^{\circ}$ Martin Buber, 'Dialogue', in Between Man and Man, trans. by Ronald Gregor-Smith (New York: Routledge, 2002), pp. I-45 (p. 4I).

${ }^{71}$ Augustine, Confessions VII.27, p. 84; referencing I Cor 4:7.

${ }^{72}$ Buber, I and Thou, p. 77.
} 
intensive or explicitly confrontational relations, for often the mere presence of an other is enough for self-development. However, this does not imply a causal hierarchy, as if we do not exist until we passively receive the stimulus of the other calling us into being; it is a simultaneous acting and being acted on..$^{73}$ Steven M. DeLue explains Buber's notion of individuation:

as I relate to others and discover my possibilities, I work to fulfill them and as I do, I end up inevitably creating new relationships or new variants of existing relationships to others, each of which makes me aware of new possibilities for myself. ${ }^{74}$

In contrast to Augustine's individualism and assumption of dependence on God, Buber presents a thoroughly interactive and social epistemology. The self is likewise conceived in very different terms. Since we are interdependent with other creatures our identity is not static and passively received but based on dynamic, ever changing relations. Even when reality or others resist our desires, such that we are dealing with a more explicit confrontation with otherness, this resistance furthers our individuation and the revelation of who we are and what is real:

But this, too, that I cannot accomplish it the way I intended it, this resistance also reveals the mystery to me ... this free human being encounters fate as the counter-image of his freedom. It is not his limit but his completion; freedom and fate embrace each other to form meaning; and given meaning, fate - with its eyes, hitherto severe, suddenly full of light - looks like grace itself.75

Reciprocity - even in the form of resistance — gives meaning, and as this meaning comes to us from the gift of the presence of the other that confronts us, even this resistance can be experienced as grace.

Where is God in this picture of creaturely interdependence and reciprocal individuation? Human beings are independent partners with God that work to create relations and the indivi-

\footnotetext{
73 Buber, I and Thou, p. 8I.

74 Steven M. DeLue, 'Martin Buber and Immanuel Kant on Mutual Respect and the Liberal State', Janus Head, 9 (2006), I I7-33 (p. I I9).

75 Buber, I and Thou, p. IO2.
} 
duation and reality that emerges out of relations. Indeed, Buber replaces the Christian notion of the consubstantiality of Father and Son with the notion of the consubstantiality of God and Man. ${ }^{76}$ Buber must walk the "narrow ridge" between, on the one hand, preserving God as uncircumscribable, and, on the other hand, relaying the human experience of theophany. He attempts to carefully capture the mysterious sense in which an all-powerful being "needs" us to enter into relationships, to individuate and be our selves, and to help draw out others, in passages such as, "How would man exist if God did not need him, and how would you exist? You need God in order to be, and God needs you - for that which is the meaning of your life" ${ }^{77}$ Contrary to Augustine's emphasis on dependence, Buber maintains that in the absence of consubstantuality no relationship with God is really possible: "Wishing to understand the pure relationship as dependence means wishing to deactualise one partner of the relationship and thus the relationship itself". ${ }^{78}$ Indeed, when prevenient grace supplants partnership - with all that implies, such as moral responsiveness - there are far reaching social and political effects. ${ }^{79}$ Once we assume radical independence and dependence, the "psychical delusion of the spirit [Seelenwahn]" that we could exist on our own, as if we were that independent God and others were mere objects and not partners worthy of moral response, is created. ${ }^{8 \circ}$ Following the "as above, so below" adage, we will be moved to imitate this image of relationship and increase centralization, domination and coercion.

One might still object the capacity to have a community founded on "functional autonomy, mutual recognition and mutual responsibility" is still an act of divine grace, for God, as our eternal I-Thou partner, is the center of community, the center that all other

${ }^{76}$ Buber, I and Thou, p. I33.

77 Buber, I and Thou, p. I30. Buber uses Nicholas of Cusa's term, "coincidentia oppositorum", to describe this mystery. For the relationship between the ideas of Buber and Nicholas of Cusa see Sarah Scott, 'Knowing Otherness: Martin Buber's Appropriation of Nicholas of Cusa', International Philosophical Quarterly 55: 4 (2015), 399-4I6.

${ }_{78}$ Buber, I and Thou, p. I 3 I.

79 Buber, Eclipse of God, p. I07.

${ }^{8 \circ}$ Buber, I and Thou, p. I4I. 
I-Thou relations depend on for their integrity. Recall that it was one of Buber's theses in "Three Theses on Religious Socialism" that socialism requires orientation to a common center. Writing of Hasidic groups, which he admired as exemplary models of community, Buber states:

The Hasidic communal group, like all genuine community, consists of men who have a common, immediate, relation to a living center, and just by this relationship have an immediate relation to one another. In the midst of the Hasidic community stands the zaddik, whose function it is to help the Hasidim, as persons and as a totality, to authenticate their relationship to God in the hallowing of life and just from this starting point to live as brothers with one another. ${ }^{81}$

We see Buber assert that community requires a common living center, which seems to cause the specific relationships among community members. We also see it is a human being - the zaddik [tsaddik, or den Bewährten] — that is placed at the center. However, this human being seems to not be a substantive center, for his function is to mediate and enable others to form relationships - first with God, and then with each other. Putting this together into a causal chain we get I) the creation of a zaddik, 2) the creation of relationships between the zaddik and other persons, 3 ) the creation of a relationship between God and those persons, 4) the creation of relationships between those persons that results in a community. But it is a mistake to seek recipes for community building. The hard truth is all four steps occur simultaneously. A leader is only a leader of a people if she is already in relation to them, and they are only a people to be in a relation with if they are already in relation with one another.

Avnon argues that the founding of a Buberian community is not a metaphysical act of grace, for the "living center" is not God, but a living person: "[the community is] prepared by individuals, not by transcendent deities". ${ }^{82}$ We might add, it is not a metaphysical act of grace unless the nature of grace is reconceived to include the unearned, always gratuitous gift of presence that creatures give to each other. These "builders of community" are the overlooked

\footnotetext{
${ }^{81}$ Buber, 'Interrogation of Martin Buber', p. 68.

82 Avnon, Martin Buber, p. I 56.
} 
foundation for the "anarcho-federalist" and "topian" socialist theories identified by Susser and Kohanski. ${ }^{8}$ Yet now the objection may be made that highlighting the leader of a community seems contrary to Buber's anarchist tendencies. How does this emphasis on the figure of the zaddik differ from Augustine's argument that submission is due to the paterfamilias and the sovereign? No submission is due to the zaddik, and he may not be a leader in the political sense at all. ${ }^{84}$ Rather, uniting Avnon's exposition with that of Fishbane, the zaddik is one who has "proved true": "These are not primarily political leaders but rather the great founders, those who established ways of life within which human beings can more fully know themselves, whose way leads to a radical reevaluation of the meaning and significance of relation". ${ }^{85}$

So far we have seen that Buber maintains that the primary gifts of grace are who we are, moral norms and reality, and we have seen how who we are and reality are simultaneously received and generated through reciprocal relations of individuation. This explanation of the zaddik helps elucidate how moral norms become received and generated. It has already been mentioned that Buber does not maintain that morality is about rule following. That would imply that morality is merely a matter of submission to a passively received law, which would run contrary to his insistence each of us is responsible for the mutual creation of the three primary gifts of grace. Instead, moral norms come to us in the form of universally valid images of fulfilled human life. In the same way artistic genius is tempered by an education in universally valid - that is, tasteful - artworks, yet never falls into mere rule following, education depends on the internalization and imitation, but not replicating or rule following, of universally valid images of humanity:

${ }^{83}$ Dan Avnon, 'The "Living Center" of Martin Buber's Political Theory', Political Theory, 21: I (Feb., I993), 55-77 (p. 60).

${ }^{84}$ On Buber's notion of political power see the argument that Buber inverts Carl Schmitt's political theology in Samuel Hayim Brody, 'Is Theopolitics an Antipolitics? Martin Buber, Anarchism, and the Idea of the Political', in Dialogue as a Trans-Disciplinary Concept, ed. by Paul Mendes-Flohr (Berlin: Walter de Gruyter, 20 I 5), 59-86.

${ }^{8}$ Avnon, 'The "Living Center" of Martin Buber's Political Theory', p. 62. 
There exist, indeed, not merely universally-valid concepts, as philosophy teaches, but also universally-valid images. The ages that possess real culture are ages where a universally-valid image of man stands above the heads of men. Looking upward to these images that are invisible and yet living in the imagination of all individuals constitutes the life of culture; the imitation of them out of the material of the person is the educating, the forming of man. ${ }^{86}$

Buber offers Socrates, Goethe, Jesus and Buddha as examples of persons who ushered in new modes of individuating and relating, new universally valid images of humanity, "proven true", that became the moral center of a community. ${ }^{87}$ The $z$ addik is just such a person, that through "proving true", serves as an exemplary model for community members. Here "proving true" means two things: the active trust mentioned earlier, and what has universal validity. Given Buber's social epistemology the latter sense of proving true cannot simply mean what is know a priori, but what, like judgments of tasteful artwork or strong defeasible arguments, are learned and contextually specific but nevertheless generally valid. ${ }^{88}$

However, the objection could be raised that if universally valid images serve as the center of community, pluralistic communities would seem to be impossible. The great historical communities may have each united around a single image, but this need not lead us to assume that another route is not possible. Indeed, Buber maintains that while most times have had a "figure of general validity - the Christian, the gentleman, the citizen”, few contemporary Western societies still have a universally valid image of humanity. Nevertheless, education and community creation can and does occur. What are educators doing if they are not merely transmitting a canon of universally valid images? In times in

${ }^{86}$ Martin Buber, 'China and Us', in Pointing the Way: Collected Essays, ed. and trans. by Maurice Friedman (New York and Evanston, IL: Harper \& Row, I963), pp. I2I-25 (p. I23).

87 Buber, I and Thou, pp. I I 5-I 6 and pp. I38-4I. Socrates, for example, is the "I of infinite conversation".

${ }^{88}$ For the relationship between Buber's moral philosophy and his use of aesthetics, especially the relation of Kantian reflective judgment to Buber's moral epistemology, see Sarah Scott, 'From Genius to Taste: Martin Buber's Aestheticism', Journal of Jewish Thought and Philosophy 25:I (20I7), IIO-3O. 
which there are no such figures of universal validity, or pluralistic figures, the only thing left to form is "the image of God ... [the educator] is set in the 'imitatio dei absconditi sed non ignoti' [an imitation of the hidden but not unknown God]" ${ }^{89}$ That the educator is to educate in imitation of God is less strange than it may sound. The educator is to not teach content so much as model a way of living and interacting through her deeds. This illustrates to students how we individuate ourselves by relating to other selves and our common human intellectual inheritance, preparing them to live in a shared reality. This is especially important insofar as the state "fosters a perspective which allows differences of interest to appear as radical opposition" and cultivates existential mistrust in its citizens, such that the citizen "believes that he has ideas, his opponent only ideologies". 90 The antidote this and the source of the social principle is education: "social education is the exact reverse of political propaganda" ${ }^{91}$ This gives us a multi-layered understanding of the center of community. There may not be a single God's Word, a single image for us to imitate. Sometimes the center is a great living spiritual leader, such as Jesus, but more commonly, "proven-true" educators hold the center, transmitting universally valid images though instruction in the canon, if one is present, and imitating God in the sense of modeling to students how to turn to each other. The "proven-true" educator is not a substantive center - not a locus of political power - but a mediating center for the social principle. Consequently, the act of grace which founds, perpetuates and builds community, is no more nor less than our own educative forces, our ability to draw out the social principle in other persons..$^{22}$ Education - which, even if transmitting a canon, always depends on living, exemplary

${ }^{89}$ Martin Buber, 'Education', in Between Man and Man, trans. by Ronald Gregor-Smith (New York: Routledge, 2002) pp. 98-IO5 (p. I2I).

90 Buber, 'The Validity and Limitation of the Political Principle', p. 216; Martin Buber, 'Hope for this Hour', in Pointing the Way: Collected Essays, ed. and trans. by Maurice Friedman (New York and Evanston, IL: Harper \& Row, I963), pp. 220-29 (p. 22I).

9г Buber, 'Society and the State', p. 176.

${ }_{92}$ Interestingly, all scenes of conversion and divine illumination in Augustine's Confessions are either communal (e.g., with his mother) or follow social transmission (e.g., learning of the life of Antony). But this is 
educators - will either teach pupils the political principle is essential and lead them to stand in "statual" relations to each other, or it will teach them the social principle is essential and will lead them to develop that community of "functional autonomy, mutual recognition and mutual responsibility".

\section{Conclusion}

In order to make sense of the various accounts of Buber's anarchism as comprised of topian-communitarian-socialist-federalistanocracy we had to investigate his notion of grace. So long as the notion of grace assumed an independent being deigning to bestow inscrutable gifts on radically dependent beings, the replication of this power structure between human beings seemed justified by the "as above, so below" adage. To reconcile religious and anarchist tendencies either the "as above, so below" principle had to be thrown out, or grace had to be redefined. We saw that Buber redefines grace by assuming radical interdependence. God and humanity are consubstantial, as are creature and creature. By focusing on interdependence Buber bypasses the antinomy of whether we are passively elected to receive gifts or willfully earn them. We receive the presence of God and other creatures, and in our response to each other we mutually exchange the gifts of individuation, moral norms and reality. We "prove true" insofar as we trust in the presence of others and work to build essential relations, that is, develop the social principle embodied in topian-communitarian-socialist-federalist-anocracies. In this analysis of grace, educators serve as the primary vehicles for the development of the social principle, and thus replace sovereign power as the center of genuine communities. Just as God gives the gift of presence, but does not elect or coerce, the centers of genuine communities give their educative presence to others, without taking on political power. Thus, to the extent that we can speak of election existing for Buber, it exists as a psycho-social problem, a problem of education.

With the notion of hierarchy and power removed from it, it may seem as if we are very far from any recognisable notion of grace.

overshadowed by his insistence we only really learn from God, the "inner teacher". 
Nevertheless, Buber repeatedly retains the term. Buber's use of the term grace is still appropriate insofar as the presence we receive whether that of God or another creature - is an excessive, undeserved gift. Who can say that they have truly earned and not received the gift of sharing a life with another being? Buber's notion of grace leaves us asking, "What is it that we have taken from others, without realising its graciousness?" and "What of ourselves are we giving in our relations to others?" In a statement of thanks that Buber wrote on the occasion of his $85^{\text {th }}$ birthday he explains that in Hebrew "the verbal form hodoth signifies first of all to avow faith in someone, after that to thank. ... to avow faith in someone means: to confirm him in his existence" ${ }^{93}$ In a similar statement, written on his $80^{\text {th }}$ birthday, he muses on to whom he must thank:

Before all to what is above. Now, indeed, so strongly as could never have been possible before, life is felt as an unearned gift ... But after that it is necessary time and again to thank one's fellow man, even when he has not done anything especially for one. For what, then? For the fact that when he met me, he had really met me, that he opened his eyes and did not confuse me with anyone else, that he opened his ears and reliably heard what I had to say to him, yes, that he opened what I really addressed, his well-closed heart. ${ }^{94}$

It must have seemed strange to Buber's Christian readers that such a prolific author of philosophic and religious studies would avoid explicit analyses of grace. The absence of a definitive statement surely contributed to the erroneous interpretations, seen above, that he was evincing a "Catholic" or "Protestant" theology. As the epigraph of this paper notes, he was asked, "why God's grace finds hardly any place in his work. He explained: 'I write theology for men, not for God'". ${ }^{95}$ Several years after responding in I and Thou

93 Martin Buber, 'Expression of Thanks, I963', in A Believing Humanism: My Testament, I902-I965, trans. by Maurice Friedman (New York, Humanity Books: I999), p. 230.

94 Martin Buber, 'Expression of Thanks, I958', in A Believing Humanism: My Testament, I902-I965, trans. by Maurice Friedman (New York, Humanity Books: I999), p. 225.

95 David Flusser, 'Afterword', in Martin Buber, Two Types of Faith: A Study of the Interpenetration of Judaism and Christianity (New York: Syracuse University Press, 2003), pp. I75-229 (p. I98). 
to Nietzsche's saying, "You take, you do not ask who it is that gives", Buber mentions the saying again. Now he warns:

As we take, it is of the utmost importance to know that someone is giving. He who takes what is given him, and does not experience it as a gift, is not really receiving; and so the gift turns into theft. But when we do experience the giving, we find out that revelation exists. ${ }^{96}$

Buber showed that anarchist and religious orientations are mutually compatible, so long as we have the proper understanding of grace. The "as above, so below" analogy can be retained because we are co-workers with God and with each other. Buber may have written "theology for men, not for God", because he realized that while his readers likely already knew that we should thank God for his presence, we can struggle with truly thanking one another for the presence that each offers to the other, that is, truly confirming and having faith in one another. Doing so might just be the first step toward a community of "functional autonomy, mutual recognition and mutual responsibility".

\section{References}

Augustine, Concerning the City of God, Against the Pagans, trans. by Henry Bettenson (London: Penguin Books, 2003).

- The Confessions, trans. by Maria Boulding (Hyde Park, NY: New City Press, 200I).

—, 'The Teacher', in Augustine: Earlier Writings, ed. by J. H. S. Burleigh (Philadelphia, PA: The Westminster Press, I953), pp. 69-IоI.

Avnon, Dan, Martin Buber: The Hidden Dialogue (Lanham, MA: Rowman \& Littlefield Publishers, Inc., I998).

— 'The "Living Center" of Martin Buber's Political Theory', Political Theory, 2I: I (Feb., I993), 55-77.

${ }^{6}$ Martin Buber, 'The Man of Today and the Jewish Bible', in The Martin Buber Reader: Essential Writings, ed. by Asher D. Biemann (New York: Palgrave Macmillan, 2002), pp. 5I-59 (p. 56). 
Brody, Samuel Hayim, 'Is Theopolitics an Antipolitics? Martin Buber, Anarchism, and the Idea of the Political', in Dialogue as a TransDisciplinary Concept, ed. by Paul Mendes-Flohr (Berlin: Walter de Gruyter, 20I 5), 59-86.

- Martin Buber's Theopolitics (Bloomington, IN: Indiana University Press, 20I8).

Buber, Martin, 'China and Us', in Pointing the Way: Collected Essays, ed. and trans. by Maurice Friedman (New York and Evanston, IL: Harper \& Row, I963), pp. I2I-25.

- 'Dialogue', in Between Man and Man, trans. by Ronald Gregor-Smith (New York: Routledge, 2002), pp. I-45.

- Eclipse of God: Studies in the Relation Between Religion and Philosophy, trans. by Maurice Friedman (Atlantic Highlands, NJ: International Humanities Press, I988).

—-, 'Education', in Between Man and Man, trans. by Ronald Gregor-Smith (New York: Routledge, 2002) pp. 98-I05.

- 'Education and World-View', in Pointing the Way: Collected Essays, ed. and trans. by Maurice Friedman (New York and Evanston, IL: Harper \& Row, I963), pp. 98-I05.

—, 'Expression of Thanks, 1958', in A Believing Humanism: My Testament, I902-1965, trans. by Maurice Friedman (New York, Humanity Books: I999), p. 225.

—-, 'Expression of Thanks, I963', in A Believing Humanism: My Testament, I902-I965, trans. by Maurice Friedman (New York, Humanity Books: I999), p. 230.

- 'Hope for this Hour', in Pointing the Way: Collected Essays, ed. and trans. by Maurice Friedman (New York and Evanston, IL: Harper \& Row, I963), pp. 220-29.

- I and Thou, trans. by Walter Kaufmann (New York: Simon and Schuster, I996).

—, 'Images of Good and Evil', in Good and Evil: Two Interpretations, pt. I: Right and Wrong, trans. by R.G. Smith, pt. 2: Images of Good and Evil, trans. by M. Bullock (Upper Saddle River, NJ: Prentice Hall, I997), pp. 63-I43. 
- 'Interrogation of Martin Buber', in Philosophic Interrogations, ed. S. and B. Rome (New York: Holt, Rinehart and Winston, I964).

, Martin Buber. A Bibliography of his Writings. I898-1978. Compiled by Margot Cohn and Rafael Buber (Jerusalem: The Magnes Press; München: K.G. Saur, I980).

, 'Martin Buber to Franz Rosenzweig, Heppenheim, June 24, I924', in The Letters of Martin Buber: A Life of Dialogue, ed. by Nahum N. Glatzer and Paul Mendes-Flohr (New York: Syracuse University Press, I996).

- 'Nationalism', in A Land of Two Peoples: Martin Buber on Jews and Arabs, ed. Paul Mendes-Flohr, (Chicago: University of Chicago Press, 2005), pp. 47-57.

- Paths in Utopia, trans. by R. F. Hull (New York: Syracuse University Press, 1996).

-, 'People and Leader', in Pointing the Way: Collected Essays, ed. and trans. by Maurice Friedman (New York and Evanston, IL: Harper \& Row, I963), pp. I48-60.

—, 'Religion and God's Rule', in A Believing Humanism: My Testament, I902-1965, trans. By Maurice Friedman (New York, Humanity Books: I999), pp. I09-I2.

- 'Right and Wrong', in Good and Evil: Two Interpretations, pt. I: Right and Wrong, trans. by R.G. Smith, pt. 2: Images of Good and Evil, trans. by M. Bullock (Upper Saddle River, NJ: Prentice Hall, I997), pp. 3-60.

— 'Society and the State', in Pointing the Way: Collected Essays, ed. and trans. by Maurice Friedman (New York and Evanston, IL: Harper \& Row, I963), pp. I6I-76.

, 'The Man of Today and the Jewish Bible', in The Martin Buber Reader: Essential Writings, ed. by Asher D. Biemann (New York: Palgrave Macmillan, 2002), pp. 5I-59.

,'The Validity and Limitation of the Political Principle', in Pointing the Way: Collected Essays, ed. and trans. by Maurice Friedman (New York and Evanston, IL: Harper \& Row, I963), pp. 208-I9.

—, 'Three Theses of a Religious Socialism', in Pointing the Way: Collected Essays, ed. and trans. by Maurice Friedman (New York and Evanston, IL: Harper \& Row, I963), pp. I I2-I4. 
- Two Types of Faith: A Study of the Interpenetration of Judaism and Christianity, trans. by Norman P. Goldhawk (New York: Syracuse University Press, 2003).

—, Martin Buber Werkausgabe, eds. Paul Mendes-Flohr and Bernd Witte (Güterloh: Güterlohsloher Verlaghaus, 200Iff.).

Cary, Phillip, Inner Grace: Augustine in the Traditions of Plato and Paul (New York: Oxford University Press, 2008).

Cohen, Richard A., 'Buber and Levinas - and Heidegger', in Lévinas and Buber: Dialogue and Difference, ed. by Peter Atterton, Matthew Calarco and Maurice Friedman (Pittsburgh, PA: Duquesne University Press, 2004), pp. 235-49.

DeLue, Steven M.,'Martin Buber and Immanuel Kant on Mutual Respect and the Liberal State', Janus Head, 9 (2006), I I 7-33.

Etzioni, Amitai, 'Communitarian Elements in Select Works of Martin Buber', The Journal of Value Inquiry, 33: 2 (I999), I 5 I-69.

Fishbane, Michael, 'Justification Through Living: Martin Buber's Third Alternative', in Martin Buber: A Contemporary Perspective, ed. by Paul Mendes-Flohr (Syracuse, NY and Jerusalem: Syracuse University Press and The Israel Academy of Sciences and Humanities, 2002), pp. I20-32.

Fitch, Richard, 'The Pelagian Mentality: Radical Political Thought in Fifth Century Christianity', in Religious Anarchism: New Perspectives, ed. by Alexandre J. M. E. Christoyannopoulos (Newcastle upon Tyne, UK: Cambridge Scholars Publishing, 2OII), pp. 2-29.

Flusser, David, 'Afterword', in Martin Buber, Two Types of Faith: A Study of the Interpenetration of Judaism and Christianity (New York: Syracuse University Press, 2003), pp. 175-229.

Friedman, Maurice, Martin Buber: The Life of Dialogue, $4^{\text {th }}$ edn. (London and New York: Routledge, 2002).

Kaufmann, Fritz, 'Martin Buber's Philosophy of Religion', in The Philosophy of Martin Buber: The Library of Living Philosophers, I2, ed. by Paul A. Schilpp and Maurice Friedman (La Salle, IL: Open Court, I967), pp. I 5 I-70.

Kaufmann, Walter, 'I and You: A Prologue', in I and Thou, trans. by Walter Kaufmann (New York: Simon and Schuster, I996), pp. 7-48. 
Kohanski, Alexander S., 'Martin Buber's Restructuring of Society into a State of Anocracy', Jewish Social Studies, 34: I (I972), 42-57.

Matthews, Gareth B., 'Augustine on the Teacher Within', in Augustine's Confessions: Critical Essays, ed. by William E. Mann (Lanham, MD: Rowman \& Littlefield Publishers, Inc., 2006), pp. 3 I-43.

Mendes-Flohr, Paul, From Mysticism to Dialogue: Martin Buber's Transformation of German Social Thought (Detroit, MI: Wayne State University Press, 1989).

Nietzsche, Friedrich, 'Ecce Homo', in On the Genealogy of Morals and Ecce Homo, trans. by Walter Kaufmann and R.J. Hollingdale (New York: Vintage Books, I989), pp. 20I-335.

Schwarzschild, Steven, 'A Critique of Martin Buber's Political Philosophy: An Affectionate Reappraisal', in The Pursuit of the Ideal: Jewish Writings of Steven Schwarzschild, ed. by Menachem Kellner (Albany: SUNY Press, I990), I 8 5-207. Originally published as "A Critique of M. Buber's Political Philosophy-An Affectionate Reappraisal,” Leo Baeck Institute Yearbook XXXI, I986, 35 5-88.

Scott, Sarah, 'From Genius to Taste: Martin Buber's Aestheticism', Journal of Jewish Thought and Philosophy 25: I (2017), I IO-30.

—_ 'Knowing Otherness: Martin Buber's Appropriation of Nicholas of Cusa', International Philosophical Quarterly 55: 4 (2015), 399-4I6.

Shonkoff, Sam Berrin, 'Metanomianism and Religious Praxis in Martin Buber's Hasidic Tales', Religions 9: I 2 (201 8): 399, https:// doi.org/I0.3390/rel9I 20399.

Susser, Bernard, 'The Anarcho-Federalism of Martin Buber', Publius, 9: 4 (I979), IO3-I 5. 